\author{
A.A. Malyshev ${ }^{1}$ and V.S. Batchenko ${ }^{2}$ \\ ${ }^{1}$ Institute of Archaeology, Russian Academy of Sciences, \\ Dm. Ulyanova 19, Moscow, 117292, Russia \\ E-mail:maa64@mail.ru \\ ${ }^{2}$ Institute of Russian History, Russian Academy of Sciences, \\ Dm. Ulyanova 19, Moscow, 117292, Russia \\ E-mail:vik-batchenko@yandex.ru
}

\title{
The Southeastern Sindica Frontier: The Raevskoye Fortified Settlement
}

The expansion of the Bosporan Kingdom (the interior colonization of Bosporus) was caused by the need for commercial grain in the Greek markets of the Mediterranean. The steep rise in the Bosporan rulers'incomes followed the annexation of Sindica-one of the most fertile lands of the Northern Pontic region, situated in the Lower Kuban basin. This study discusses the history of the vast chora of the Greek Gorhippia in the southeastern fringes of Sindica, focusing on findings from a Bosporan fort-the Raevskoye fortified settlement. We reconstruct the evolution of the anthropogenic landscape of the area over four centuries (Hellenistic and Early Roman period). The chronology is based on a collection of Bosporan coins from the fortified settlement. We analyze the factors due to which the habitation layers of the fortified settlement span a period from the Early Bronze Age to the High Middle Ages. We provide a new topography of the Early Iron Age aboriginal site, along with that of the fortified site existing during the three Bosporan stages. Special attention is paid to the fortification system, arranged in the Hellenistic period. Studies in recent decades have suggested that the fortifications were constructed according to the typical Bosporan technique of adobe-stone architecture. The fortified settlement evolved over a long period as an economic and political center of a large borderland zone between the Greek civilization and the archaic societies of the Caucasian piedmonta peculiar frontier of the classical era.

Keywords: Bosporan Kingdom, contact area, fortification, frontier, Hellenistic period, Early Roman period.

\section{Introduction}

The Bosporan Kingdom, which emerged ca $480 \mathrm{BC}$ from the union of Greek poleis on the shores of the Cimmerian Bosporus (now, the Kerch Strait), gained economic power and political influence in the ancient world from largescale wheat export. The expansion of possessions, in particular in Sindica (Strabo, VII.IV.6), which was one of regions most abundant in grain crops in the Northern Black Sea region, was largely aimed at increasing export opportunities. The borders of the region, which was named after one of the indigenous tribes - the Sindi people ( $\Sigma$ ıvooí), were the Gipanis (now Kuban) River in its lower reaches, and the spurs of the Greater Caucasus mountain range. According to the titles of the Bosporus rulers $\left(\mathrm{KBN}^{*}\right.$ 6, 6a, 39, 40, 1014, 1037, 1038, 1042), in the 4th century BC, the Sindi people, like the Sindi Harbor, which was renamed Gorgippia (Pseudo-Scymnus, 888), were subordinate to the Bosporus. According to

Archaeology, Ethnology \& Anthropology of Eurasia 48/2 (2020) 69-79 E-mail: Eurasia@archaeology.nsc.ru (C) 2020 Siberian Branch of the Russian Academy of Sciences

(C) 2020 Institute of Archaeology and Ethnography of the Siberian Branch of the Russian Academy of Sciences (C) 2020 A.A. Malyshev, V.S. Batchenko 
archaeological evidence, the process of the intra-Bosporan colonization was manifested in the formation of chora of the Gorgippia polis, extending up to $20 \mathrm{~km}$ (Alekseeva, 1997: 22-23) and reaching the southeastern borders of Sindica (Anfimov, 1987: 90) (the Anapa Valley) later, in the Hellenistic period ( 3 rd to 2 nd centuries BC).

In the Early Iron Age, the right bank of the Kuban River was outlined by a chain of fortified settlements (Kamenetsky, 1989: Map 21, p. 235), while the no less convenient steep slopes of the Anapa Valley rivers (Anapka, Maskaga, and Kotlama) remained almost unused. This fact emphasizes the importance of the fortified settlement founded in the middle part of the Anapa Valley, on the right bank of the Maskagi River. The advantages of that fortified settlement, known in the 19th century as Nogai-Kale (the Nogai fortress), were summarized by one of the first researchers of these places, V.I. Sizov, according to whom the fortress was conveniently located relative to the river and land communications not only in the Anapa Valley, but also in the entire Abrau Peninsula; it literally "reigned" over the area (1889: 112).

On the ground plan published by Sizov, the fortress had a configuration that was more typical of fortifications of the Modern Age, constituting a polygon of a rampartlike embankment with eight tower-shaped ledgesbastions (Fig. 1, 1) (Ibid.: Pl. XXV). Excavations in the northeastern corner of the Raevskoye fortified settlement revealed the ruins identified by Sizov as the "barracks of the Early Roman (?) period". Therefore, he dated this monument to Antiquity, and linked it with the "Sindi fortress" of Ptolemy and the "Aboraka" of Strabo (Ibid.: 113-117, 132). New data from spatial stratigraphy and the chronology of the Raevskoye fortified settlement became available in the 1950s-1960s. Cultural layers were identified in its north-northwestern part, under the rampart-like embankment of the fortress; one of the layers was associated with the horizon of the monumental complex of the 3 rd -2 nd centuries BC. N.A. Onaiko identified two periods of the fortification system at the settlement: 2nd-1st centuries BC and 1st-2nd centuries AD (1984: 92).

The strategy for conducting comprehensive archaeological excavations at the Raevskoye fortified settlement, which were resumed in 1998, resulted from remotely surveying the terrain and features of the monument located in that terrain, using aerial photography of the mid and third quarter of the 20th century (Fig. 1, 2-4), satellite photography of 2018, as well as instrumental surveys of the ancient settlement within the rampart-like embankment (performed by M.O. Zhukovsky). A two-level system of defensive structures, with the "citadel" in the northeastern part, was discovered. As a rule, survey works preceded excavations:
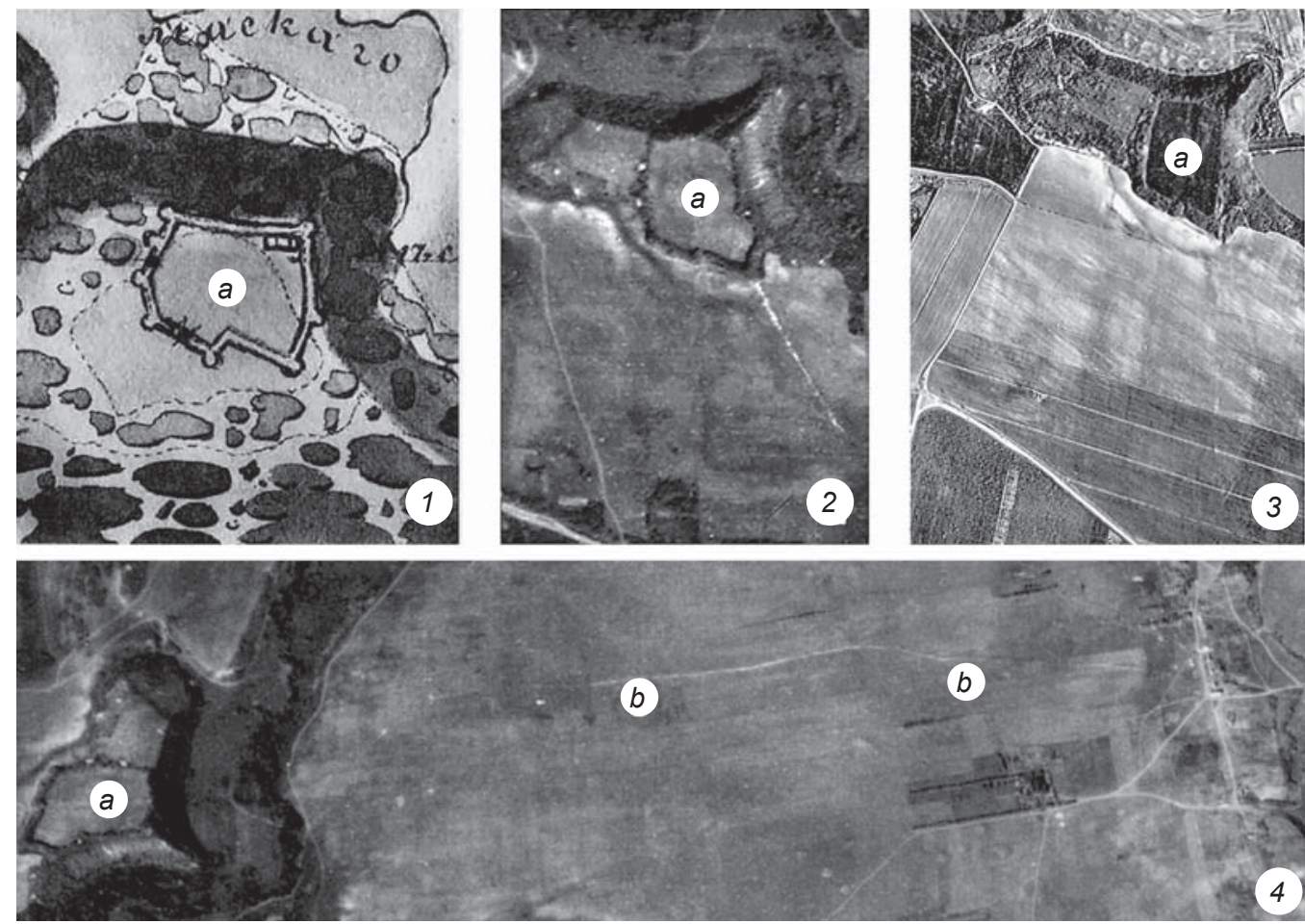

Fig. 1. Landscape features of the fortress.

1 - ground plan of the Nogai-Kale fortified settlement, 1880s; 2, 4- aerial photographs of the 1940s; 3 - aerial photograph of the 1970s. $a$-Raevskoye fortified settlement; $b$-rampart to the north of the settlement. 


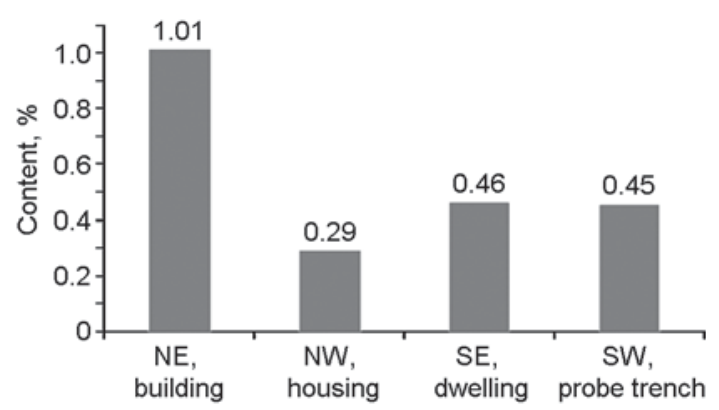

Fig. 2. The content of gross phosphorus in the layers of the Raevskoye fortified settlement.

about $11 \%$ of the total area (ca 1 ha) has been studied by magnetic survey, including almost all tower structures.

Excavations unearthed $3.4 \%$ ( $0.35 \mathrm{ha})$ of the entire area $(8.71 \mathrm{ha})$ of the settlement. The thickness of the cultural layers, as well as their phosphorus content (Fig. 2), have revealed the sophisticated vertical and horizontal stratigraphy of the site. Its existence from the Chalcolithic and the Early Bronze Age to the High Middle Ages turned out to be the longest for the entire Abrau Peninsula. At the same time, almost all of the buildings studied, despite the rather unusual outlines of the fortress, have been confidently dated to Antiquity. The duration of the Bosporus presence (from the late 4th century BC to the mid 1st century AD) can be evaluated on the basis of the numismatic evidence (Fig. 3).

Thus, exploring the evolution of the anthropogenic landscape at the Raevskoye fortified settlement for four centuries (the Hellenistic and Early Roman periods) plays a key role in the study of the Bosporus colonization at the foothills of the Northwestern Caucasus. The fortification complex deserves special attention, since (judging by the comprehensive work by V.M. Ivanov (2005)) the observation of the leading Russian scholar of Antiquity V.D. Blavatsky that the data accumulated in scholarship "are so fragmentary and random that, relying on them, it is absolutely impossible to outline a general picture of defensive and siege warfare in the Black Sea region" (1950: 145) remains valid until now.

\section{Studying the evolution of anthropogenic landscape}

One of the starting points of these studies is the collection and systematization of evidence regarding the original landscape before the Antiquity, based on remote sensing data: on the north, the outer contours of the settlement are outlined by the high bank of the Maskagi River; on the west and south, a very clear natural boundary is formed by a ravine connected to the valley of the meandering Maskagi River. The talweg of the ravine was indicated on the plan of Sizov, and is clearly visible in the aerial photograph; it has an extensive water catchment area (see Fig. 1, 1-3). Judging by its irrigation canals, the area adjacent to the settlement on the south was susceptible to swamping (see Figs. 1, 4), which clearly complicated the access to the settlement. This fact contradicts the suggestion of Sizov, who argued that both entrances, main and auxiliary, were on the side facing Anapa (1889: 112). Thus, unimpeded access to the territory of the settlement was possible only from the eastern side, along the high bank of the Maskagi River.

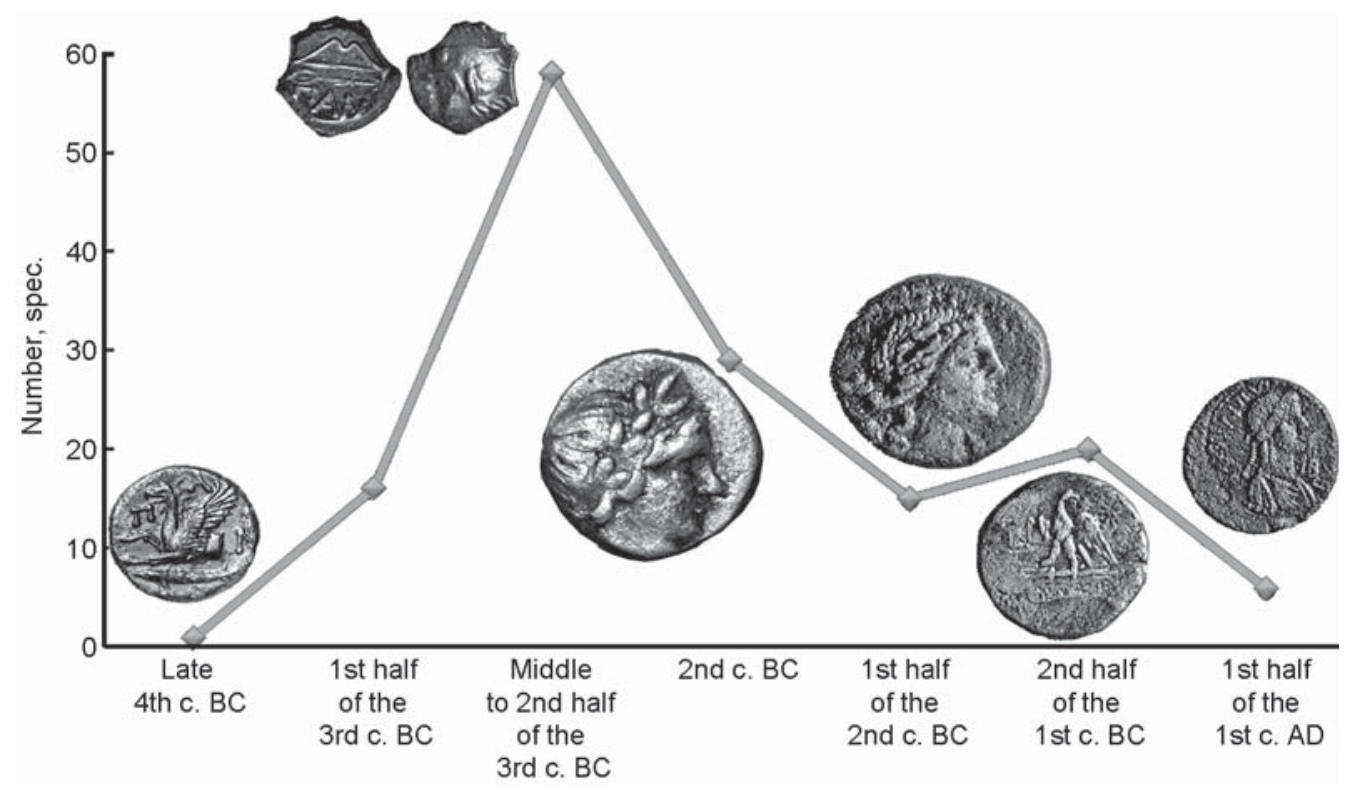

Fig. 3. Chronology of the Bosporus presence at the Raevskoye fortified settlement according to numismatics. 

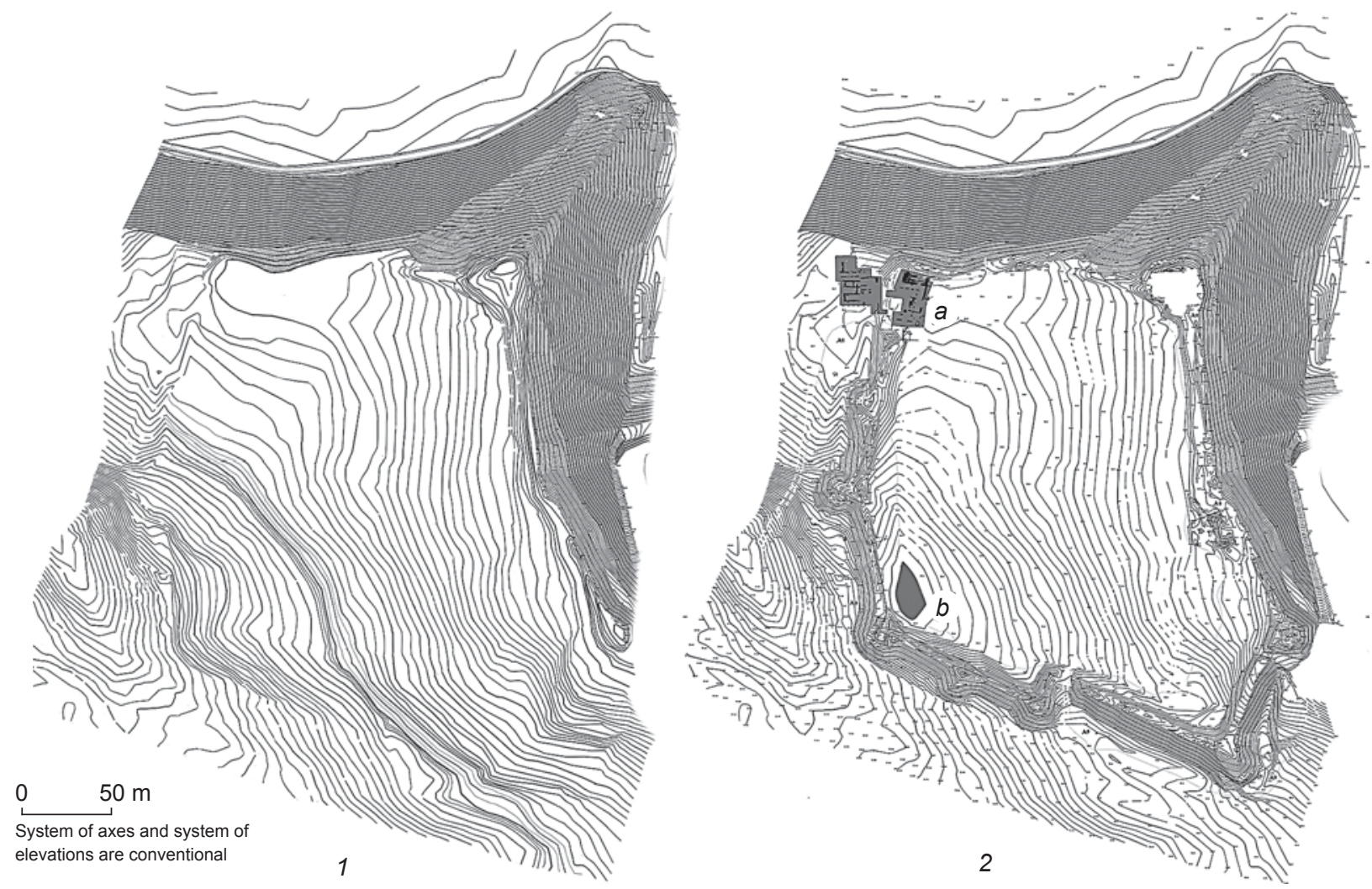

Fig. 4. Terrain of the Raevskoye fortified settlement.

1 - before Antiquity; 2 - anthropogenic landscape of Antiquity ( $a$ - monumental complex of the Hellenistic period; $b$ - reservoir formed by the rampart-like embankment).

The terrain at the site was no less expressive: the height difference was almost $14 \mathrm{~m}$; the highest place was in the eastern part, and the lowest part was in the southwestern corner. The shallow areas convenient for settlement stretched along the high bank of the Maskagi River, decreasing stepwise from east to west (Fig. 4, 1). On the aerial photograph of the 1940 s, they are distinguished by a darker color; surfaces with a larger angle of inclination to the south clearly appear lighter (see Fig. 1, 2, 3).

As a rule, the inhabited sites are tied to a water source. The aquifer at the Raevskoye fortified settlement, like the surrounding area, has a significant inclination in the southwestern direction*. Thus, the western part of the area is most suitable for settlement, which is confirmed by the presence of a cultural layer of the pre-Greek period, where a small quantity of mostly amphora-type pottery of the 5th-4th centuries BC have been found, testifying to sporadic contacts between the Greek and Barbarians.

The Bosporus presence at the settlement is indicated by the cultural remains of the Hellenistic period (3rd2nd centuries BC), which have been found everywhere at

*A well outside the embankment has survived until our time. the site. The composition of the finds (numerous coins, a wide range of antique pottery, including cultic terracotta, and lamps) is comparable to the evidence from the settlements of Antiquity on the Black Sea coast.

The topography of the Hellenistic buildings does not fit the outline of the Raevskoye fortress, well known to us from the time of Sizov, which is more consistent with the above-mentioned pre-antique landscape. In particular, a high-status complex oriented relatively precisely to the cardinal directions (according to Hippodamian Plan), was built over the area of about 0.15 ha (Fig. 5) on the place of the indigenous settlement of the Early Iron Age in the western part of the settlement, in the safest place (taking into account the landscape-related features of the site) and in the immediate vicinity of the water source.

The filling of the premises and the height of the stonework of local rocks (sandstones and limestones) suggest the use of the typical Bosporus technique of erecting adobe walls on a stone basement (of adobe-stone architecture) (Kryzhitsky, 1984: 202). They were built according to a purely Greek tradition, which involved the flatwise placement of blocks. Stretchers alternated with binders, usually without back filling; for strengthening the structure, elongated blocks ( $\delta \alpha \tau$ ovor) were inserted in such 
a way that their end surfaces appeared in both faces of the wall (Vitruvius, II.VIII.7). More compliant imported shell rock was used for manufacturing architectural elements.

There is a lot of evidence indicating the high status of the complex owner. The thickness of stone walls (up to $1.6 \mathrm{~m}$ ) suggests that buildings in the northern part had two levels. On the outside, the walls were covered with white single-layer plaster, and on the inside with two-layer plaster, on which fragments of polychrome mural paintings have been preserved. Similar to public and sacred buildings in the centers of mainland Greece* and Panticapaeum (Kryzhitsky, 1993: 149, fig. 102), there was a closed peristyle courtyard in the core of the complex. It has survived in the form of a portico stylobate of processed shell rock blocks placed $2 \mathrm{~m}$ from each other, with bases of columns surviving on some of them. The walls of the courtyard were decorated with polychrome painting. The monumental building was "crowned" by a tiled roof, which was typical of the Greek tradition. Judging by the numerous "EYME $\Lambda O Y$ " stamps, its elements were made in the town workshops of Gorgippia, and were apparently delivered by the Maskagi River, navigable at the time.

The almost complete absence of hearth structures and an unusually low phosphorus content in the cultural layers (see Fig. 2) testify to the low intensity of using the
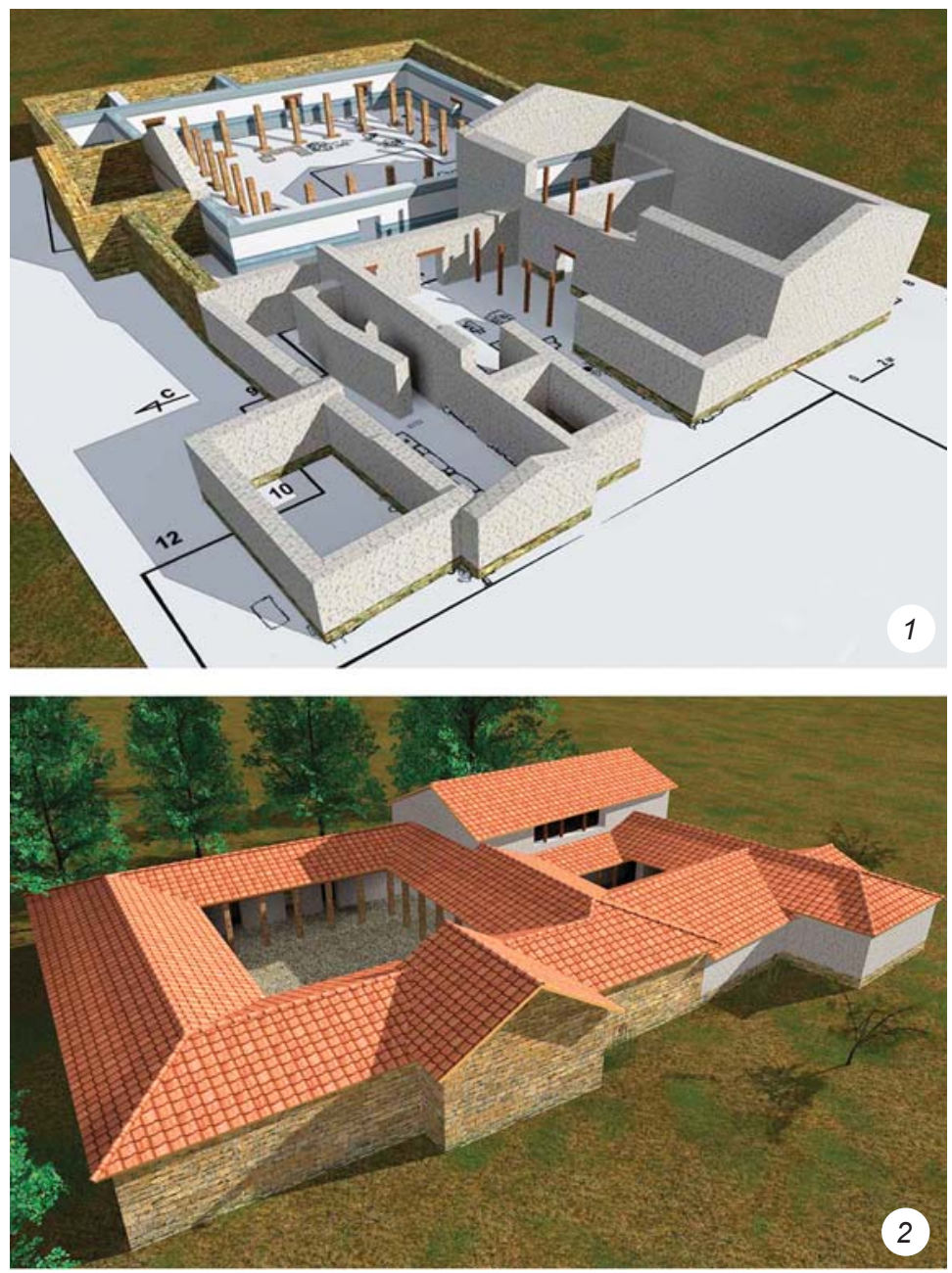

Fig. 5. Monumental structure of the Hellenistic period (3D reconstruction of the building was made by V.V. Moor). premises in the complex. Ordinary residents of the settlement lived in houses of wicker coated with clay, typical of the local house-building traditions for thousands of years. The remains of burnt grounds (floors or hearth structures) have been found in the northwestern and southeastern parts of the settlement.

The construction of such a prestigious architectural complex testifies to the extreme interest in the territories located at a considerable $(20 \mathrm{~km})$ distance from the Black Sea coast. The intense economic and political activities of the Bosporians in this frontier region without a doubt were accompanied by military danger due to inevitable armed conflicts with the population of the neighboring territories. In this regard, the need for constructing fortifications had to arise in the $3 \mathrm{rd}$ century $\mathrm{BC}$. The blank outer walls of the monumental complex could hardly provide the necessary security.

*Prytaneion in Olympia, Heroon of Calydon, and palace complex in Larissa (Lawrence, 1957: 219-221, fig. 89-90, 123; p. 245, fig. 138).
As we have mentioned above, the landscape features of the site primarily required protection of the eastern approaches (see Fig. 1; 4, 2). The northern part of the eastern border, described by Sizov as the main frontal surface of the fortress (1889: 112), was located in the area dominating the heights of the settlement: it passed along the ridge of a steep and extended slope. Therefore, the southeastern border had to be secured first and foremost. The main difficulty in creating fortifications was a significant $(5-6 \mathrm{~m})$ height difference over the 80-meter stretch. The erection of a substructure of a powerful multi-meter rampart-like embankment compensated for this drop and largely made it possible to avoid slope deformations. Defensive ramparts were typical of both Greek and "barbarian" fortifications of the Northern Black Sea region. However, on the Abrau Peninsula, they became widespread, like building in stone, during the period of the Bosporus development of the region. Research into the structure of the embankment has revealed that it was built from disintegrated products of local flysch rocks. It was 
possible to date two humus horizons of buried soil under the embankment*. The first horizon (level $65-80 \mathrm{~cm}$ ) was formed not earlier than $2380 \pm 110$ BP (IGAN-2450), according to calibrated data-in the period from the 8th to the late 3rd century $\mathrm{BC}$; for the second horizon (level $130-150 \mathrm{~cm}$ ), the date of $3250 \pm 180 \mathrm{BP}$ was obtained (IGAN-2451), which indicates the development of soil in the exposed mode for at least a thousand years. The dating results make it possible to speak about the beginning of intensive earthworks in the construction of the defensive rampart in the Hellenistic period.

The southeastern and hundred-meter wide southern sections of the rampart-like embankment flank the three largest towers in the system of the Raevskoye fortress. To this day, they have been preserved in the form of rounded mound-like hills $5 \mathrm{~m}$ high, like the rampart. Excavations have revealed** that fortifications were made in the adobe-stone technique typical of Bosporus. The stone bases of the towers have survived to the height of $4 \mathrm{~m}$, and the defensive walls adjacent to them have survived up to $1.5 \mathrm{~m}$ high.

The towers were multi-level structures of a rectangular shape up to $10 \mathrm{~m}$ high (Koltukhov, 1999: 64). For ensuring the stability of the walls in the fortifications, large blocks of sandstone (especially in the foundation rows), stepwise expansion of stonework towards the base, and buttresses were used. The embankments around the remains of the towers resulted from the destruction of walls in the upper levels. In some places, it was possible to trace the disintegrated rows of adobe bricks, which significantly differed in size (about $0.2 \times 0.2 \times 0.4 \mathrm{~m}$ ) from the usual Bosporus bricks (Kuznetsov, 2015: 289), and more likely correspond to pentadorone blocks for public buildings (Vitruvius, II.III.3).

If the Eastern tower located at the highest point of the Raevskoye fortified settlement slightly protruded beyond the line of the rampart-like embankment, the Southeastern (corner) and Southern (1) towers extended far beyond the ramparts because of the postern-gallery (Fig. 6, 1, 4, $6,7)^{* * *}$, which compensated for the length of curtain walls, exceeding the usual aiming range of the arrow (40$60 \mathrm{~m}$ ) (Medvedev, 1966: 32), and also made it possible to control the movements from east to west in the area south of the fortress. Thus, small groups of professional

* Radiocarbon analysis was performed by O.A. Chichagova in the Laboratory of Radiocarbon Dating and Electron Microscopy at the Institute of Geography of the Russian Academy of Sciences.

**All towers were excavated, and the areas of the Eastern and Southern towers (1) were fully explored.

***In Ancient Greece, this building method had been known from the 6th century BC: Eleusis, towers 4 and 7 (6th century BC) (Adam, 1982: 198, fig. 112); Macedonia, Mount Goritsa, tower 29 (4th century BC) (Bakhuizen, 1986: fig. 130, 132). archers dispatched on the three towers described above could control the $180 \mathrm{~m}$ long perimeter of the fortress.

The arrangement of access and the location of passage structures are important features, which, as we know, was a necessary but usually weak link in any fortification system. The Southeastern (angular) and Southern (1) towers, built far beyond the boundaries of the fortress, formed a ricetto, in the corner of which the passage structure could have been located. In addition to the two towers, the access to the entrance was complicated from the north by a five-meter embankment, and from the south by a ravine.

Instrumental and aerial photography recorded the rise to the fortified settlement along the ridge of the promontory (see Fig. 1, 2, 3; 4). A relatively small slope made it possible to use it not only for horse and pedestrian traffic, but also for wheeled vehicles. In recent years, the remains of a sentinel tower with a square layout $(7 \times 7 \mathrm{~m})$ (Fig. 7) were excavated on the northeastern promontory. The tower made it possible to control access to the passage structure located apparently to the west of the northeastern promontory. The tower was included in the system of defensive walls on the northern and northeastern side of the fortress, along the edge of a high bank, which were built on the mainland rock and not on rampart substructure. These walls were somewhat thinner than the stonework of the towers (about $1.2 \mathrm{~m}$ ); traces of the internal gallery along these walls have not been found, which suggests their use as adobe-stone fence 3-4 m high.

Thus, the data derived from archaeological research in recent decades confirm the conclusions of N.A. Onaiko about the existence of fortifications in the 2nd century BC within the known perimeter (see Fig. 4, 2). Along with burials of the indigenous population (the Sinds, Torets, and Kerkets) in the vicinity of the Raevskoye fortified settlement, an extensive burial ground was studied, showing the placement of a bowl under the head of the buried person, typical of the Maeotian rite (Malyshev, 2007: 138). The presence of the carriers of the Maeotian culture has been established in the pottery complex from the Southern tower of the settlement (see Fig. 6, 3). Apparently, the need for fortifications was caused by the changes in the ethnic and political situation on the southeastern borders of Sindica - in the middle part of the Anapa Valley.

The construction of a rampart-like embankment over abandoned buildings of the monumental Hellenistic complex indicates radical changes in the fortification system of the Raevskoye fortified settlement. The layout of the fortress was reoriented in the meridional direction. The resulting fortification system manifests a sharp decrease in the height of the rampart-like embankment and the sizes of tower hills from east to west, as well as an up to $40-50 \mathrm{~m}$ doubling of the tower front. The southwestern curtain wall, blocking the runoff of surface 


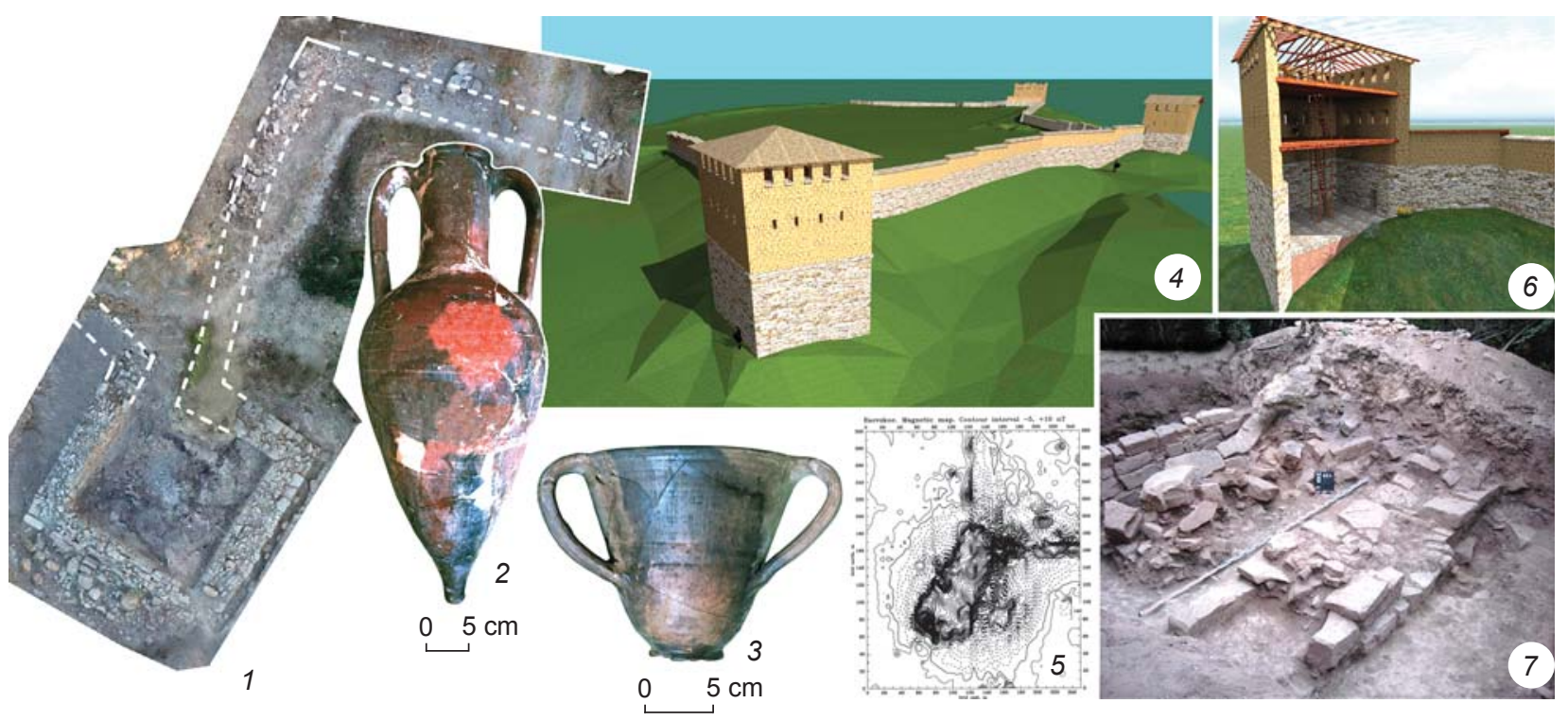

Fig. 6. Tower structures of the Raevskoye fortified settlement.

Southern tower (1): 1 - orthophotographic plan of the tower and adjacent walls; 2 - Late Sinop amphora (late 2nd century BC); 3 - gray-polished "Maeotian" kantharos with three handles. Southeastern tower: 4, 6-3D reconstruction of the structure (by V.V. Moor); 5 -results of magnetic survey (1998, by T.N. Smekalova); 7 - stone walls of the postern leading to the tower structure.

and groundwater, has a noticeable length $(80 \mathrm{~m})$. Thus, the reorientation of the outer contours of the fortress in the meridional direction can be explained by the desire to secure the approaches not only to the "citadel", but also to the water source, which was important for ensuring the inhabitants' autonomy in the case of siege. Unlike the monumental Hellenistic complex, where there is no evidence of destruction and all evidence points to a gradual desolation, traces of powerful war-related (?) fires have been found in the ruins of tower structures in the external defensive complex, whose existence and destruction were dated to the Hellenistic period (see Fig. 6, 2). Despite many years of research, residential and fortification adobe-stone structures of the Hellenistic period in the deeper areas of the Anapa Valley have been found only at the Raevskoye settlement. This may point to small number in the Bosporus population in the region, and there are more likely political rather than economic reasons for large-scale construction at the fortified settlement.

Serious changes in the ethnic and political situation of the Gorgippia chora also occurred in the Early Roman period (1st century $\mathrm{BC}$ to 1 st century $\mathrm{AD}$ ). In addition to the disappearance of a network of Hellenistic estates in the vicinity of the ancient polis, assimilation of vast spaces of the Abrau Peninsula by the Maeotian people has been observed against the background of an almost complete absence of the indigenous Sindi-Kerket sites belonging to that period (Malyshev, Batchenko, 2018: Pl. 1). At the same time, around the turn of the Common Era, the area with the traditions of Bosporus adobe-stone architecture reached its maximum, outlining the new borders of the Gorgippian chora. The preservation of the borderland nature of the region and a rigid (possibly militarized) organization of economic activities is confirmed by the spread of fortified multi-level and multi-chamber buildings both in Gorgippia (house 60) (Alekseeva, 1997: 84, 128-129), as well as throughout the entire Abrau Peninsula (Vyazkova, Golieva, Malyshev, 2009).

Owing to its convenient geographical position, the Raevskoye fortress turned into the central core of a large cluster of settlements scattered throughout the entire Anapa Valley. Building activities and evidence from the Early Roman period, like at the early stage of the Bosporan presence there, were concentrated along the bank of the Maskagi River. However, the "citadel" moved to the promontory part of the northeastern corner of the fortified settlement. It had a rectangular shape and an area of $0.12 \mathrm{ha}$. On the side facing a possible enemy attack (western and southern), the citadel was protected by the $2 \mathrm{~m}$ thick fortress wall. The haste of its construction is manifested by placement of stonework upon the cultural layer of the Hellenistic period, as a result of which it sinks deeply into utility pits in several places (see Fig. 7, 3).

The wall defended the monumental structure, which began to be studied by Sizov in the 1880 s, as we have mentioned above. The stonework of three semi-basement rooms with thick (up to $1.2 \mathrm{~m}$ ) external walls, as well as a number of structural solutions, indicates similarities with tower-like multi-level structures on the Abrau Peninsula. For instance, the resistance of a two- or three-level 

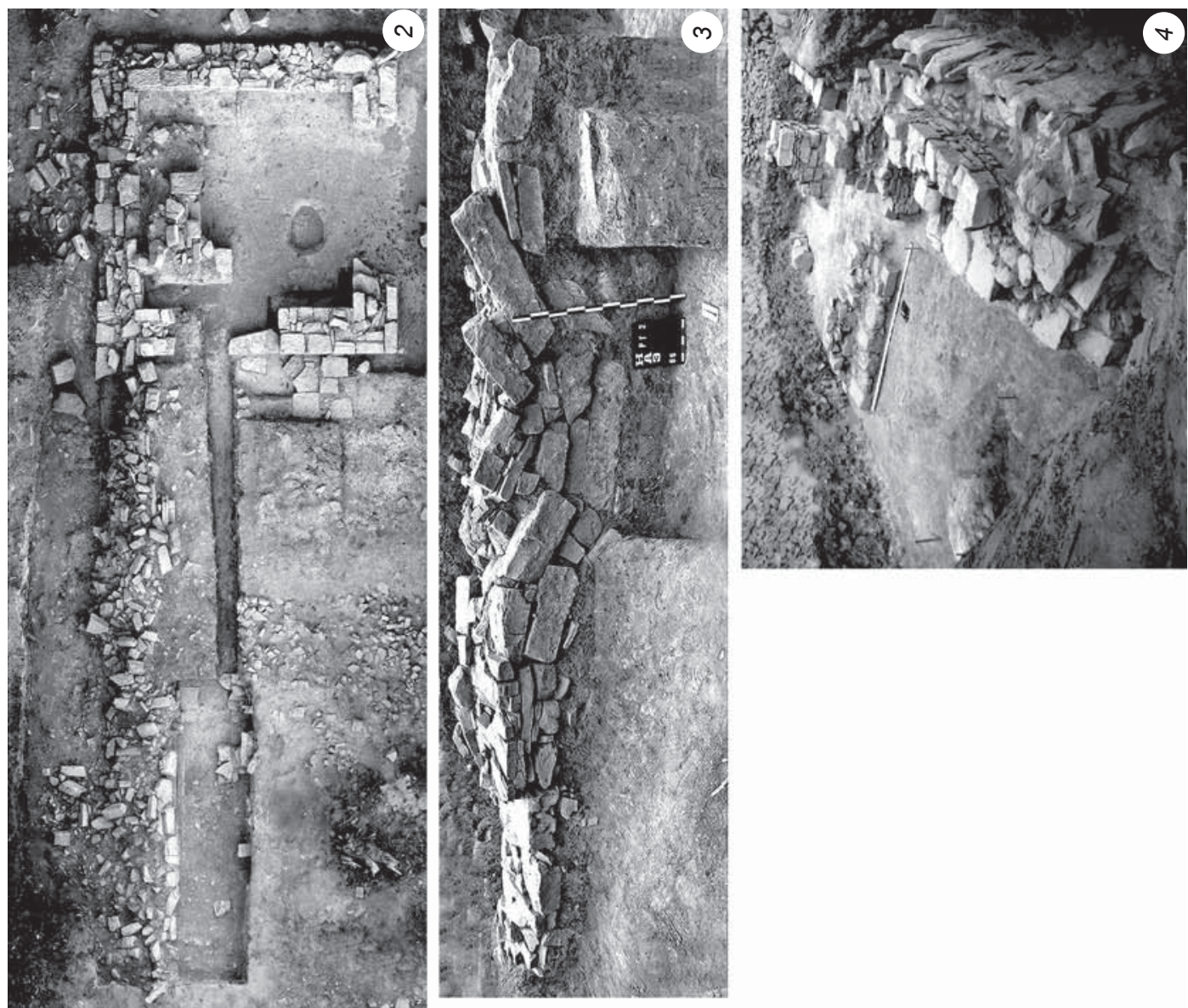

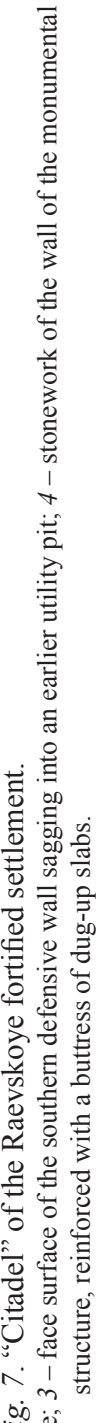

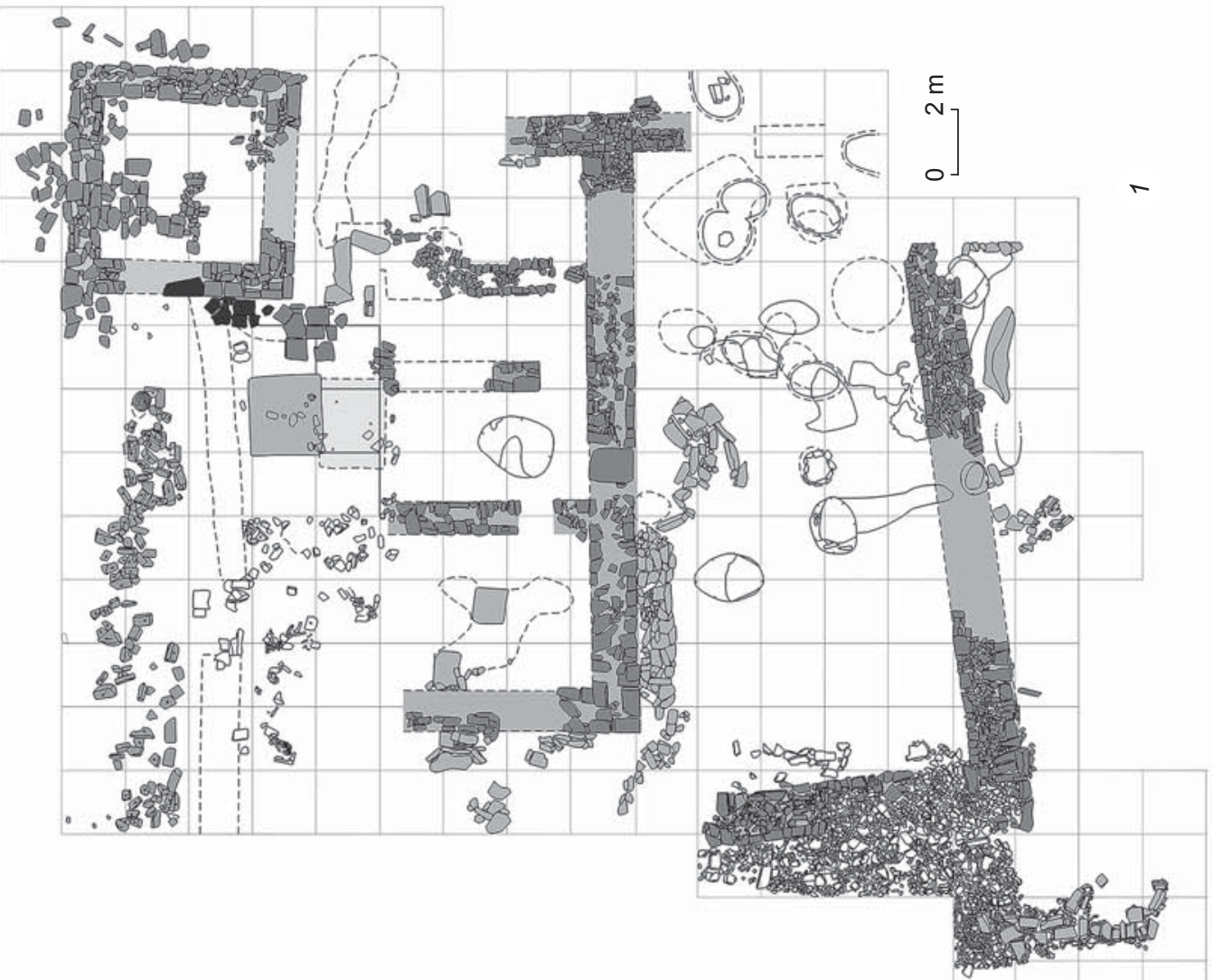

定

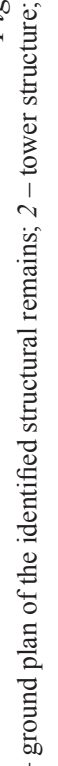



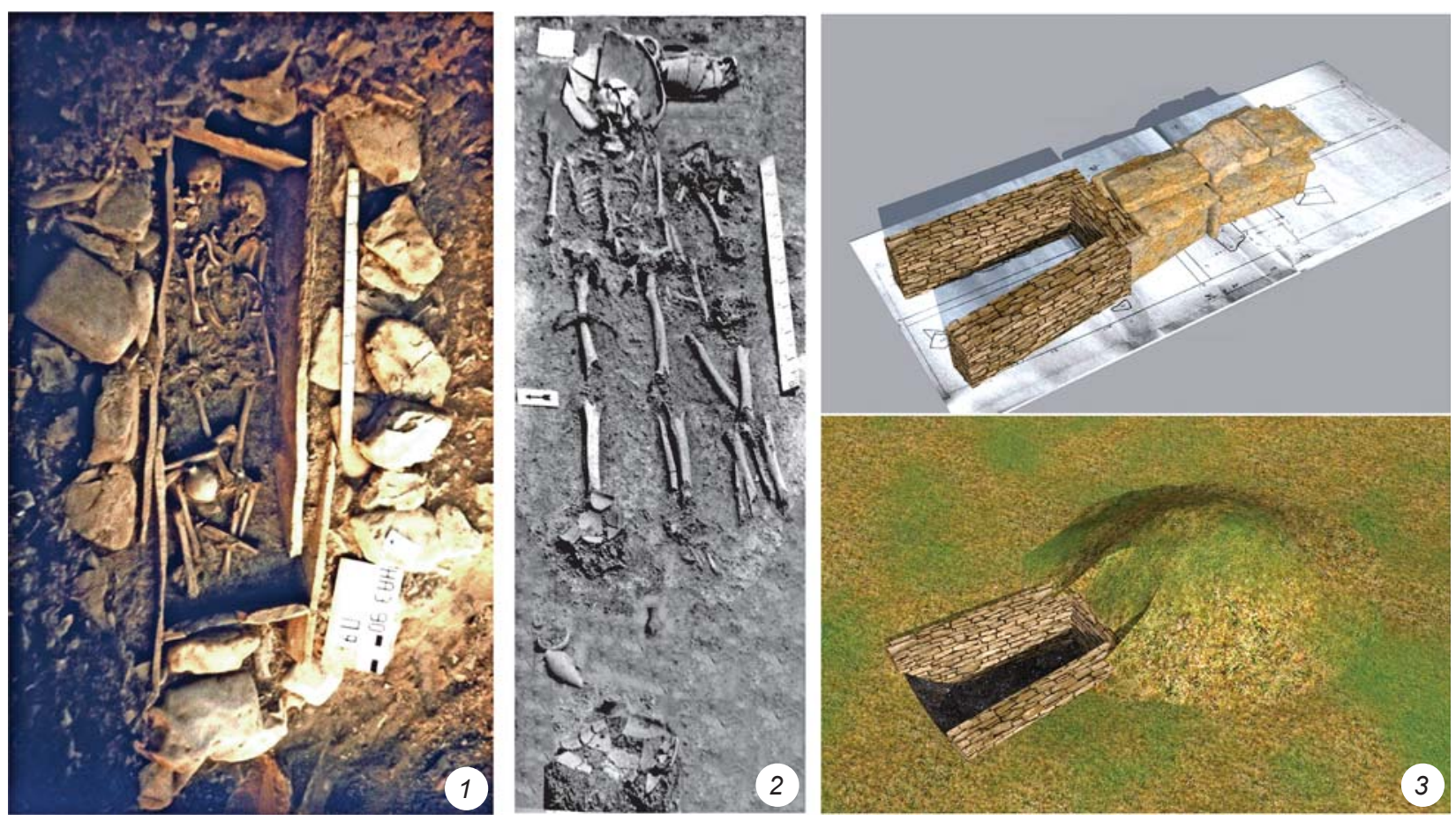

Fig. 8. Burials of various cultures, illustrating the ethnic and political situation in the southeast of the Bosporus during the Hellenistic period.

1 - burial in the stone box, belonging to indigenous population of the foothills (Lobanova Shchel cemetery); 2 - burial according to the Maeotian rite (vicinity of the Raevskoye fortified settlement); 3 - antique burial in a stone crypt (Shum-rechka).

building to longitudinal deformation*, as is also the case with the structure at the Rassvet settlement (Ibid.: 219220), was ensured not only by the general massiveness of the foundation part, but also by the buttresses made of massive blocks (about $0.6 \times 1.4 \mathrm{~m}$ in size) and set up on the west and southwest.

The military defeat of the fortress is also manifested by the traces of fire that destroyed the structures of the "citadel", and numerous remains of its inhabitants of various ages found at different levels of the ruins and on the adjacent area. The latest numismatic evidence of this period, such as the coins of Mithridates III (38-45 AD), has made it possible to date these events to the mid 1st century AD (see Fig. 3).

In addition to a large number of container vessels (amphorae and pithoi) of Antiquity, agricultural tools, a set of stone-cutting tools, and a whole arsenal of weaponry were found in the western room on the lower level of the "citadel", covered with ashes from the conflagration. Thus, the inhabitants of the fortress included military troops, farmers, and builders. We often have to speak about the economy of this settlement in general terms, since traces of artisanal production have been found in the areas inhabited for three or four

\footnotetext{
*In the latitudinal direction, a meter difference in height along the length of the building (about $19 \mathrm{~m}$ ) has been observed.
}

centuries, and testify to the spread of technologies and economic practices of Antiquity in the region.

\section{Discussion}

The evidence analyzed above testifies to the key role of the ancient center on the high bank of the Maskagi River (Raevskoye fortified settlement) in strengthening and expanding the Bosporus presence in vast expanses of the foothills of the Northern Caucasus to the east of the ancient Gorgippia. The unstable development of this region was also associated with natural and climatic conditions (a peculiar combination of the steppe and mountain landscapes, northeastern hurricane bora winds, increased average annual rainfall) (Vyazkova, 2009), as well as ethnic and political instability (with a location on the ancient border inhabited by the indigenous tribes of the foothills- "meek" Sinds and "pirating" Kerkets and Torets, on whose possessions the inhabitants of the Kuban plains periodically encroached) (Fig. 8) (Malyshev, 1995).

The Bosporus settlement at the Raevskoye fortress, remote from the Black Sea coast by dozens of kilometers, developed for a long period as the economic and political center of vast borderland between the civilization of Antiquity and archaic communities of the foothills 
(a kind of frontier* of Antiquity). The frontier nature of its environs is confirmed both by the data of a member of the Society of the Local Historians of the Kuban Region A.S. Lizarev, who discovered a system of earthen fortifications (ditch and rampart) north of the Nogai-Kale settlement (Gorodishche Nogai-Kale, 1924: 163), and by aerial survey materials from the 1940s (see Fig. 1, 4, b).

The arrangement of the defense system of the settlement reveals the great expertise of its creators. On the one hand, they successfully used sophisticated terrain, and on the other hand, they made the fortifications to have a ground plan close to a geometrically correct figure. The flank defense system based on the density of the tower front may indicate the peripheral nature of this center, which could have had a rather small military unit at its disposal.

\section{Conclusions}

The magnitude of changes in the anthropogenic landscape at the settlement during the Hellenistic period is emphasized by numerous finds of coins (3rd2nd centuries BC). The Hellenistic Tanais in the delta of the Don River (Arsenieva, 1984: 93) and the settlement of Elizavetinskoye in the Middle Kuban region (Gorodtsov, 1936: 172), which existed in the same period, provide a rationale for the argument that the ancient center on the banks of the Maskagi River (Raevskoye fortified settlement) was not a local phenomenon, but one of many testimonies to the most significant territorial expansion of the Bosporan Kingdom. Undoubtedly, the main task of this peripheral center throughout the entire period of its existence was to ensure the military and economic presence of the Bosporians in the southeast of Sindica. Despite the flourishing of Gorgippia after the military defeat in the mid 1st century BC (Alekseeva, 1997: 129-130), its vast chora gradually fell into decline, apparently owing to drastic changes in the ethnic and political situation, together with the priorities of economic activities (Malyshev, Trebeleva, 2018: 149-150), and thus the need to maintain a fortress in the depths of the Anapa Valley also disappeared.

\footnotetext{
*This concept was proposed a century ago by F. Turner to describe the historical and cultural process of development of the Wild West (2009: 13-43). It implies a synthesis of geographical and historical space. Further studies have shown the universal nature of the concept of frontier as borderland or zone of interaction between two or more cultures or political structures (Riber, 2004: 199). The complexity and versatility of this phenomenon has been observed; its most important structural element is the state of unstable equilibrium (primarily natural extremeness combined with military and political instability) (Zamyatina, 1998: 75-82).
}

\section{Acknowledgments}

This study was part of the "New Aspects in Studying Fortification in the Asian Bosporus (4th century BC to 6th century AD): Discoveries, Research Methodologies, Visualization Capacities" Project of the "Monuments of Material and Spiritual Culture in the Modern Information Environment" (I.25) Sub-Program for Basic Research of the Presidium of the Russian Academy of Sciences. Field research was supported by the Russian Foundation for Basic Research (Project No. 17-29-04313/18).

\section{References}

\section{Adam J.-P. 1982}

L'architecture militaire grecque. Paris: Picard.

Alekseeva E.M. 1997

Antichniy gorod Gorgippiya. Moscow: Editorial URSS.

Anfimov N.V. 1987

Drevneye zoloto Kubani. Krasnodar: Kn. izd.

Arsenieva T.M. 1984

Tanais. In Antichniye gosudarstva Severnogo Prichernomorya. Moscow: Nauka, pp. 93-95. (Arkheologiya SSSR; vol. 9).

\section{Bakhuizen S.C. 1986}

La grande batterie de Goritsa et l'artillerie defensive. In $L a$ Fortification dans l'histore du monde grec: Actes du Colloque intern. "La fortification et sa place dans l'histoire politique, culturelle et sociale du Monde Grec". Valbonne, Dec. 1982. Paris: Éd. du Centre nat. de la recherche sci., pp. 315-321. (Colloques intern. du Centre nat. de la recherche sci. / Centre de recherches archéologiques).

\section{Blavatsky V.D. 1950}

Materialy po antichnoy fortifikatsii v Severnom Prichernomorye. Ucheniye zapiski Moskovskogo gosudarstvennogo universiteta, iss. 143: 126-150.

\section{Gorodishche Nogai-Kale. 1924}

In Izvestiya Ob-va lyubiteley izucheniya Kubanskogo kraya, iss. VIII, B.M. Gorodetsky (ed.). Krasnodar: pp. 162-163.

\section{Gorodtsov V.A. 1936}

Yelizavetinskoye gorodishche i soprovozhdayushchiy yego mogilnik po raskopkam 1935 goda (predvaritelnoye soobshcheniye). Sovetskaya arkheologiya, No. 1: 171-186.

\section{Ivanov V.M. 2005}

Grecheskaya fortifikatsiya Severnogo Prichernomorya VI pervoy poloviny I vv. do n.e.: Cand. Sc. (History) Dissertation. Mosk. Gos. Univ. im. M.V. Lomonosova. Moscow.

\section{Kamenetsky I.S. 1989}

Meoty i drugiye plemena Severo-Zapadnogo Kavkaza v VII v. do n.e. - III v. n.e. In Stepi yevropeiskoy chasti SSSR $v$ skifo-sarmatskoye vremya. Moscow: Nauka, pp. 224-251. (Arkheologiya SSSR; vol. 11).

Koltukhov S.G. 1999

Ukrepleniya Krymskoy Skifii. Simferopol: SONAT.

Korpus bosporskikh nadpisey. 1965

Moscow, Leningrad: Nauka.

Kryzhitsky S.D. 1984

Stroitelnaya tekhnika. In Antichniye gosudarstva Severnogo Prichernomorya. Moscow: Nauka, pp. 201-204. (Arkheologiya SSSR; vol. 9). 


\section{Kryzhitsky S.D. 1993}

Arkhitektura antichnykh gosudarstv Severnogo Prichernomorya. Kiev: Nauk. dumka.

Kuznetsov V.D. 2015

Syrtsoviy kirpich (po materialam Fanagorii). Problemy istorii, filologii, kultury, No. 1: 282-295.

Lawrence A.W. 1957

Greek Architecture. London: Penguin Books Ltd.

Malyshev A.A. 1995

$\mathrm{K}$ voprosu o prichernomorskoy lokalnoy gruppe meotskoy kultury. Bosporskiy sbornik, No. 6: 151-157.

Malyshev A.A. 2007

Pogrebalniy obryad i planigrafiya Raevskogo nekropolya. In Yugo-vostochnaya periferiya Bospora v ellinisticheskuyu epokhu: Po materialam Raevskogo nekropolya. Moscow: Grif i K, pp. 137-141. (Nekropoli Chernomorya; vol. I).

Malyshev A.A., Batchenko V.S. 2018

Poluostrov Abrau v antichnuyu epokhu (istoriograficheskiy ocherk). Problemy istorii, filologii, kultury, No. 4: 78-93.

Malyshev A.A., Trebeleva G.V. 2018

Evolyutsiya sistemy rasseleniya $\mathrm{v}$ periferiynykh rayonakh aziatskogo Bospora (na primere poluostrova Abrau). Problemy istorii, filologii, kultury, No. 3: 143-156.

Medvedev A.F. 1966

Ruchnoye metatelnoye oruzhiye (luki i strely, samostrely). Moscow: Nauka. (SAI; iss. E1-36).

Onaiko N.A. 1984

Raevskoye gorodishche, Torik. In Antichniye gosudarstva Severnogo Prichernomorya. Moscow: Nauka, pp. 92-93. (Arkheologiya SSSR; vol. 9).

\section{Riber A. 2004}

Menyayushchiyesya kontseptsii i konstruktsii frontira: Sravnitelno-istoricheskiy podkhod. In Novaya imperskaya istoriya postsovetskogo prostranstva. Kazan: Tsentr issledovaniy natsionalizma i imperii, pp. 199-222. (Biblioteka zhurnala “Ab Imperio").

\section{Sizov V.I. 1889}

Vostochnoye poberezhye Chernogo morya: Arkheologicheskiye ekskursii. Moscow: (Tip. A.I. Mamontova i $\mathrm{K}^{\circ}$ ). (Materialy po arkheologii Kavkaza; iss. II).

Turner F.D. 2009

Frontir v amerikanskoy istorii. Moscow: Ves mir.

Vyazkova O.E. 2009

Rol prirodno-geograficheskogo faktora $\mathrm{v}$ formirovanii antropogennogo landshafta na poluostrove Abrau. In $A B R A U$ ANTIQUA: Rezultaty kompleksnykh issledovaniy drevnostey poluostrova Abrau. Moscow: Grif i K, pp. 11-18.

Vyazkova O.E., Golieva A.A., Malyshev A.A. 2009

Bosporskaya signalno-storozhevaya sistema na poluostrove Abrau: Rezultaty kompleksnykh issledovaniy. In $A B R A U$ ANTIQUA: Rezultaty kompleksnykh issledovaniy drevnostey poluostrova Abrau. Moscow: Grif i K, pp. 212-240.

\section{Zamyatina N.Y. 1998}

Zona osvoyeniya (frontir) i eyo obraz v amerikanskoy i russkoy kulturakh. Obshchestvenniye nauki i sovremennost, No. 5: 75-88.

Received September 30, 2019. Received in revised form December 9, 2019. 